\title{
STRUKTUR KOMUNITAS PLANKTON PADA TIGA ZONA DENGAN VARIASI SALINITAS DI LABUAN CERMIN KECAMATAN BIDUK-BIDUK, KAB. BERAU, KALIMANTAN TIMUR
}

\author{
Dian Aspiyani. B, Nova Hariani*, Medi Hendra \\ Program Studi Biologi FMIPA Universitas Mulawarman \\ *E-mail: nova.ovariani@gmail.com
}

\begin{abstract}
The aim of this study is to know about the quality of the waters from the structure of community and level of diversity plankton on three zones vertically with variety salinity on labuan cermin, at Biduk-biduk, Kalimantan Timur. The sample is taken by used method purposive sampling. The data acquired and showed in profusion plankton form, index abundance, index diversity, index evenness, and index dominance. The plankton has found during the research is 79 genera classified in 46 family and 13 class. The index abundant is on station $A$ is the highest than the other station. On the average of index diversity of station A higher than station $B$ and $C$ in value about 2,3026. Index evenness revolve from 0,1870 to 0,8281. Index dominance revolve about 0,1171 to 0,7885.

Keywords: Estuary, plankton, Labuan Cermin, diversity.
\end{abstract}

Di wilayah perairan pesisir terdapat empat ekosistem yang khas yang merupakan tempat hidup yang berbeda bagi biota laut, yaitu estuari, terumbu karang, mangrove dan lamun. Estuari merupakan tempat bertemunya perairan air tawar dan perairan air laut atau asin yang berasal dari sungai atau drainase yang berasal dari muara sungai, teluk maupun rawa pasang surut (Ariyana dan Yuliana, 2012). Perairan pesisir dan laut terdiri dari komponen abiotik (fisika-kimia) dan biotik (organisme) yang berhubungan satu sama lain dan saling berinteraksi membentuk suatu struktur fungsional. Jika komponen tersebut mengalami perubahan terutama perubahan pada faktor abiotiknya, maka akan sangat mempengaruhi factor biotik yang hidup di dalam perairan tersebut seperti bentos, ikan, plankton, algae, tumbuhan dan masih banyak lagi. Beberapa organisme yang sangat rentan terhadap perubahan lingkungan habitatnya dapat dijadikan indikator biologi atau bioindikator (Fachrul, 2006).

Plankton sebagai komponen dasar dalam struktur kehidupan di perairan, yaitu sebagai produsen perairan dapat dijadikan sebagai salah satu parameter dalam pemantauan kualitas lingkungan perairan (Thoha, 2004). Plankton merupakan organisme yang hidup melayang di dalam badan perairan. Plankton dapat dibagi menjadi dua, yaitu fitoplankton dan zooplankton (Radiarta, 2012). Organisme ini mempunyai kemampuan bergerak yang sangat 
terbatas, sehingga sebaran organisme ini sangat dipengaruhi oleh kondisi arus perairan. Selain itu, tingkat kehadiran plankton juga dipengaruhi oleh besarnya kisaran salinitas pada suatu perairan. Banyaknya perbedaan salinitas antar titik di suatu perairan akan membuat persebaran plankton menjadi rendah. Sebab, zooplankton air tawar akan mengkerut jika memasuki kawasan yang hipertonik (memiliki kadar salinitas tinggi), sehingga hanya plankton yang toleransi terhadap air payau saja yang berkembang (Fachrul, 2006).

\section{Labuan Cermin merupakan} suatu kawasan perairan yang menjorok jauh ke daratan atau yang sering disebut dengan teluk. Labuan Cermin merupakan salah satu badan perairan yang mempunyai keistimewaan karena memiliki perbedaan salinitas antara bagian permukaan, tengah dan dasarnya. Pada bagian permukaan terdiri dari air tawar, sedangkan pada bagian tengah dan mengarah ke dasar perairan terdiri dari air asin. Adanya perbedaan salinitas di Labuan Cermin ini, serta lokasi ini sudah menjadi tempat pariwisata, sehingga perlu diketahui bagaimana struktur komunitas planktonnya. Laporan maupun studi tentang hal tersebut belum ada. Oleh karena itu, perlu dilakukan penelitian tentang struktur komunitas plankton di Labuan Cermin ini. Tujuan studi ini adalah untuk mengetahui kualitas perairan baik dari segi fisika dan kimia serta struktur komunitas dan tingkat keanekaragaman plankton pada tiga zona secara vertikal dengan variasi salinitas di Labuan Cermin, Kec. Biduk-biduk, Kab. Berau, Kalimantan Timur.

\section{METODE}

1. Waktu dan Tempat

Penelitian ini dilaksanakan dimulai dengan pengambilan sampel di Labuan Cermin Kec. Biduk-biduk Kab. Berau Kalimantan Timur, selanjutnya sampel diidentifikasi di laboratorium Ekologi dan Sistematika Hewan, Fakultas Matematika dan Ilmu Pengetahuan Alam, Universitas Mulawarman, Samarinda.

\section{Variabel Penelitian}

Parameter Utama yang digunakan untuk mengetahui struktur komunitas plankton yang meliputi kelimpahan, keaneka-ragaman, keseragaman dan dominansi. Parameter penunjang yang digu-nakan adalah kualitas fisika dan kimia, kualitas fisika meliputi kekuatan arus dan suhu, sedangkan kualitas kimianya meliputi TDS (Total Dissolved Solid), salinitas dan derajat keasaman $(\mathrm{pH})$.

3. Teknik Sampling

Penentuan titik sampling dipilih secara acak (purposive sampling), penentuan lokasi ini mengacu pada fisiografi lokasi agar dapat mewakili keadaan dari perairan tersebut (Hasnawijaya, 2012). Berdasarkan keadaan fisiografi lokasi penelitian, maka lokasi sampling dibagi menjadi tiga zona atau stasiun. Pengambilan sampel plankton setiap stasiun dilakukan sebanyak 4 kali pengulangan dengan 3 titik utama secara vertikal yaitu pengambilan yang dilakukan pada kedalaman 0 meter, 4 meter dan 8 meter pada badan perairan.

4. Teknik Pengambilan Data

a. Alat dan Bahan

Alat-alat yang diperlukan diantaranya GPS (Global Positioning System), pompa air, pipa, gayung, selang, water 
checker, Plankton-Net, botol sampel, sprayer, ember, genset, kamera, pipet tetes, object glass, cover glass, cawan petri, mikroskop, alat tulis, kalkulator dan buku panduan identifikasi plankton.

Bahan-bahan yang digunakan antara lain sampel plankton, tissue, kertas label, aquadest, air bersih dan formalin $40 \%$.

b. Prosedur Kerja

$$
\text { Pengambilan }
$$

sampel

dilakukan di 3 stasiun. Sebelum sampel plankton diambil, ditentukan titik koordinat dengan menggunakan GPS di setiap titik. Untuk mendapatkan hasil yang akurat, dilakukan pengulangan sebanyak 4 kali, dilakukan pengukuran kondisi fisik kimia perairan pada pagi hari sebelum melakukan sampling. Salinitas, suhu, $\mathrm{pH}$ dan TDS diukur dengan menggunakan water checker, kemudian dicatat hasilnya. Air sampel disaring menggunakan Plankton-Net, kemudian dipindahkan ke botol sampel dan formalin $40 \%$ diteteskan sebanyak 1-2 tetes, serta diberi label. Sampel plankton yang telah diperoleh, dibawa ke laboratorium untuk diidentifikasi. Kemudian dihitung kelimpahan plankton yang diperoleh dan dianalisis kelimpahan plankton,indeks keanekaragaman, indeks keseragaman dan indeks dominansinya..

5. Analisis Data

Struktur komunitas plankton diketahui melalui parameter kelimpahan plankton (N), indeks keanekaragaman jenis $\left(\mathrm{H}^{\prime}\right)$ dan indeks dominansi (D).

$$
\begin{aligned}
H^{I} & =\sum_{i=1}^{s} p i \operatorname{Ln} p i=\frac{n i}{N} n i \\
D & =\left(\frac{n i}{N}\right)^{2}
\end{aligned}
$$

\section{HASIL DAN PEMBAHASAN}

1. Faktor fisika dan kimia perairan di Labuan Cermin

Untuk mengetahui kualitas suatu perairan, maka diperlukan adanya pengukuran beberapa parameter kualitas air yang meliputi sifat fisika dan kimia perairan yang dapat dilihat pada Tabel 1. Hasil pengukuran pada Tabel 1 menunjukkan bahwa rata-rata suhu air, TDS dan kekuatan arus termasuk normal untuk pertumbuhana plankton disutau peraiaran. Perbedaana salinitas didapatkan berdasarkan kedalam mulai dari permukaan air yaitu 0,66-25 \%o yang menandakan bahwa daerah Labuan Cermin termasuk daerah air payau/estauri. Nilai $\mathrm{pH}$ yang didapatkan selama penelitiana adalah 6,75-7.07 yang tergolong baik untuk pertumbuahan plankton. Menurut Banerjea (1967), suatu perairan dengan $\mathrm{pH}$ antara 5,5-6,8 termasuk tidak produktif, kisaran 6,5-7,5 termasuk produktif dan kisaran 7,5-8,5 mempunyai produktifitas yang tinggi. Effendi (2003) menambahkan bahwa sebagian besar biota akuatik sensitif terhadap perubahan $\mathrm{pH}$ dan menyukai nilai $\mathrm{pH}$ sekitar 7-8,5.

Hasil penelitian menunjukan bahwa ditemukan 13 kelas (Gambar 1). Jumlah individu dari masingmasing stasiun di setiap titik berbeda karena dipengaruhi oleh banyak faktor. Adanya perbedaan kelimpahan plankton setiap 


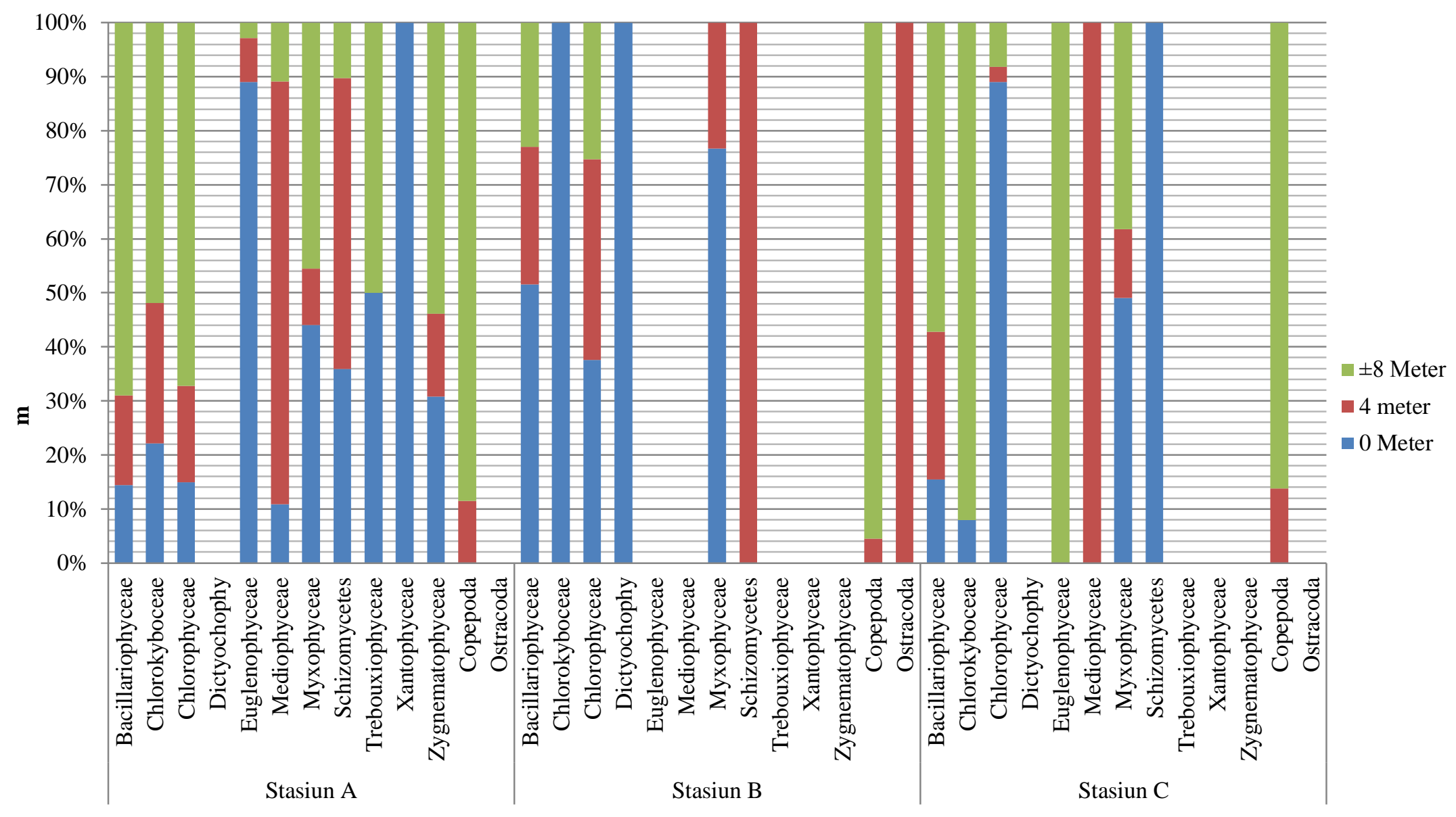

Gambar 1 Komposisi dan Kelimpahan Plankton di Setiap Stasiun Berdasarkan Kelasnya. 


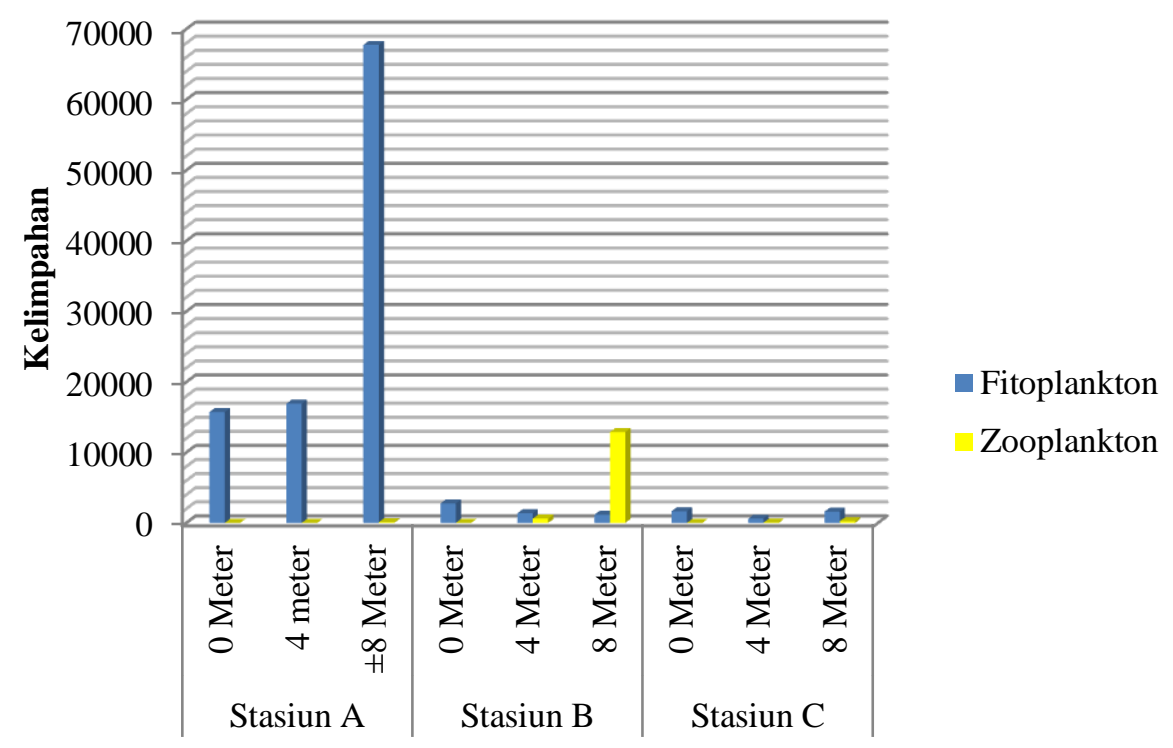

Gambar 2. Kelimpahan Fitoplankton dan Zooplankton Stasiun A, B dan C.

tempat, dipengaruhi oleh tingkat kesuburan perairan. Sesuai dengan klasifikasi perairan yang dikemukaan oleh Suryanto (2011) yang dikelompokkan menjadi 3, maka perairan Labuan Cermin termasuk dalam kelompok perairan Eutrofik. Karena nilai kelimpahannya > $15.000 \quad$ ind/L. Kelas Bacilariophyceae (diatom) dan
Chlorophyceae merupakan kelompok plankton yang paling banyak dan ditemukan hampir diseluruh stasiun dan titik. Nontji, (2008) mengatakan bahwa diatom merupakan fitoplankton atau tumbuhan mikroskopis laut karena memiliki kemampuan fotosintesis yang tidak kalah dengan tumbuhan di darat.

Tabel 1. Rerata Hasil Pengukuran Faktor Fisika Kimia Perairan di Labuan Cermin

\begin{tabular}{|c|c|c|c|c|}
\hline \multirow{2}{*}{\multicolumn{2}{|c|}{ Parameter Lingkungan }} & Stasiun A & Stasiun B & Stasiun C \\
\hline & & Rata-rata & Rata-rata & Rata-rata \\
\hline $\mathrm{pH}$ & & 6,75 & 6,79 & 7,07 \\
\hline \multirow{3}{*}{ Salinitas $(\%$ 。o $)$} & Kedalaman $0 \mathrm{~m}$ & 0,71 & 0,61 & 0,66 \\
\hline & Kedalaman $4 \mathrm{~m}$ & 15 & 12 & 7,5 \\
\hline & Kedalaman $\pm 8 \mathrm{~m}$ & $>25$ & $>20$ & $>15$ \\
\hline \multicolumn{2}{|l|}{ TDS (ppm) } & 716 & 515.5 & 562.5 \\
\hline \multicolumn{2}{|c|}{ Kekuatan Arus (m/s) } & 1,432 & 1,231 & 1,324 \\
\hline
\end{tabular}

Gambar 1 terlihat bahwa persebaran kelas Bacilariophyceae paling tinggi dibandingkan kelas lainnya pada 3 stasiun dan masing-masing 3 titik 
vertikalnya. Keada stasiun B di kedalaman 8 meter, kelompok dengan persebaran genus dan spesies tertinggi ditemukan pada kelas Copepoda. Menurut Sachlan (1982),Bacillariophyceae dan Chlorophyceae merupakan plankton terbanyak dan terpenting dalam perairan, baik tawar maupun laut sebagai produsen primer, terutama pada permukaan air yang penuh zat hara. Fitoplankton yang hidup pada kisaran salinitas diatas $20 \%$ sebagian besar merupakan plankton dari kelompok diatom (Bacillariophyceae).

Kelas Chlorokybophyceae, dengan satu genus yaitu Chlorokybus sp. Graham (2015), menyatakan bahwa Chlorokybophyceae adalah salah satu indikator peraiaran yang belum tercemar Kelimpahan fitoplankton dan zooplankton dapat dilihat pada Gambar 2. Secara keseluruhan fitoplankton (11 kelas) memperlihatkan kelimpahan yang paling tinggi dibandingkan zooplankton (dua kelas). Kelimpahan fitoplankton sangat berbeda nyata antar stasiun. Stasiun A memiliki kelimpahan fito yang snagat tinggi sedangkan pada stasiun B dan C kelimpahan plankton didominasi oleh zooplankton. Adapun kelompok zooplankton yang didapatkan sebanyak 2 kelas, yaitu kelas
Copepoda dan Ostracoda. Kelas zooplankton yang paling banyak ditemui pada seluruh stasiun adalah dari kelas Copepoda. Kelas Copepoda dikenal sebagai kelas zooplankton yang kosmopolitan atau dapat hidup dan beradaptasi di perairan yang berbeda salinitas. Oleh karena itu, kelimpahan kelas ini juga tinggi walaupun di dasar perairan sekalipun.

2. Indeks keanekaragaman Indeks keanekaragaman pada 3 stasiun dengan 3 titik vertikalnya dapat dilihat pada Tabel 2 . Berdasarkan Tabel 2 di atas terlihat Indeks Keanekaragaman tertinggi adalah pada stasiun A denngan ratarata 2,637 dan yang terendah di stasiun B yaitu 1,362. Indeks Keanekragaman tertinggi berdasarkan kedalaman dan slainitas ditemukan pada kedalama 4 meter yaitu 2,285. Kondisi perairan di lokasi penelitian yang diukur secara stratifikasi vertikal tergolong perairan yang memiliki tingkat keaneragaman genus yang tergolong rendah. Jika mengikuti penggolongan tingkat indeks keanekaragaman Shannon-Winner dalam Begon (1986), nilai rerata indeks keanekaragaman spesiesnya pada semua titik kedalaman termasuk rendah. Karena H' yang didapatkan $H^{\prime}<2,3086$, yaitu 2,2847.

Tabel 2. Hasil perhitungan Indeks Keanekaragaman (H') Per Stasiun dan Per Titik Secara Vertikal

\begin{tabular}{ccccc}
\hline \multirow{2}{*}{ Stasiun } & \multicolumn{3}{c}{ Titik Vertikal } & \multirow{2}{*}{ Rata-rata Per Stasiun } \\
\cline { 2 - 4 } & 0 Meter & 4 Meter & \pm 8 Meter & \\
\hline A & 2,799 & 2,702 & 2,410 & 2,637 \\
B & 1,749 & 1,759 & 0,580 & 1,363 \\
C & 1,056 & 2,393 & 2,272 & 1,907 \\
\hline Rata-Rata & 1,868 & 2,285 & 1,754 & 1,969 \\
\hline
\end{tabular}


3. Indeks Dominansi

Indeks Dominansi pada 3 stasiun dengan 3 titik vertikalnya dapat dilihat pada Tabel 3. Tabel 3. memperlihatkan bahwa hasil ratarata perhitungan indeks dominansi (D) di tiga stasiun pengamatan dengan masing-masing tiga titik secara vertikal reratanya berada pada kisaran 0,117 hingga 0,789 . Secara umum nilai indeks Dominanasi berada dalam kategori tidak terdapat spesies yang mendominanasi kecuali pada stasiun B pada kedalaman 8 meter $(0,789)$ dan $\mathrm{C}$ pada kedalaman 0 meter $(0,5405)$ terdapat spesies yang mendominasi yaitu genus Synura sp. (titik 0 meter stasiun C) dan Acanthocyclops sp. (titik 8 meter stasiun B).

Tabel 3 Hasil perhitungan Indeks Dominansi (D) Per Stasiun dan Per Titik Secara Vertikal

\begin{tabular}{ccccc}
\hline \multirow{2}{*}{ Stasiun } & \multicolumn{3}{c}{ Titik Vertikal } & \multirow{2}{*}{ Rata-rata Per Stasiun } \\
\cline { 2 - 4 } & 0 Meter & 4 Meter & \pm 8 Meter & \\
\hline A & 0,124 & 0,095 & 0,149 & 0,123 \\
B & 0,171 & 0,243 & 0,789 & 0,410 \\
C & 0,541 & 0,117 & 0,127 & 0,262 \\
\hline Rata-Rata & 0,279 & 0,152 & 0,355 & 0,262 \\
\hline
\end{tabular}

Menurut Sanders et al. (1987) dalam Abida (2008), faktor-faktor lingkungan yang mempengaruhi dominansi satu spesies adalah cahaya, temperatur dan bentuk kimia nutrien lainnya. Hal ini didasarkan kriteria Odum (1994), yang menyatakan bahwa kisaran nilai dominan 0-0,50 menunjukkan bahwa daerah tersebut tidak ada spesies yang mendominansi. Genus Acanthocyclops sp. dari kelas Copepoda merupakan kelompok terbesar Crustacean (Levinton, 2001), sehingga dalam jumlah dan biomassa copepoda melebihi semua kelompok zooplankton. Nugraha et al. (2007), menyatakan bahwa Copepoda selalu terdapat di setiap tingkat kedalaman mulai dari 0 meter hingga 30 meter, jenis serta spesiesnya bervariasi untuk setiap ordo. Oleh karena itu, di perairan Labuan Cermin pada kedalaman 8 meter juga banyak ditemui plankton dalam kelompok Copepoda ini. Jumlah spesies Copepoda adalah sebanyak 1.506, sehingga dia dikenal juga dengan nama serangga lautan (Costello, 2000; Humes 1994).

\section{SIMPULAN DAN SARAN}

Berdasarkan data yang didapatkan dan setelah dilakukan pengolahan data, maka dapat disimpulkan sebagai berikut.

1. Jika dilihat dari parameter fisika, Labuan cermin memiliki rata-rata suhu sekitar $24,5-26,5^{\circ} \mathrm{C}$, rata-rata kekuatan arus sekitar 1,23-1,43 $\mathrm{m} / \mathrm{s}$. Adapun parameter kimianya, Labuan Cermin memiliki rata-rata TDS 515- 716 ppm, rata-rata derajat keasaman $(\mathrm{pH})$ sekitar 6,77,2 dan rata-rata salinitas pada kedalaman 0 meter adalah $0,66 \%$, kedalaman $4 \mathrm{~m}$ adalah $>12 \%$ dan kedalaman $8 \mathrm{~m}$ adalah $>25 \%$. 
2. Total kelas yang ditemukan di Labuan Cermin 13 kelas. Kelimpahan palnkton berkisar 644 ind/L - 67.846 Ind/L Indeks keanekaragaman tertinggi pada stasiun A adalah pada kedalaman 0m $\left(\mathrm{H}^{\prime}=2,7988\right)$, sedangkan pada stasiun B $\left(H^{\prime}=1,7591\right)$ dan C $\left(H^{\prime}=2,3934\right)$ pada kedalaman $4 \mathrm{~m}$, yang masuk dalam kategori keanekaragaman dan kestabilan komunitas sedang. Karena $H^{\prime}>2,3026$ (stasiun A dan C) dan $\mathrm{H}^{\prime}<2,3026$ (stasiun B). Nilai Indeks dominansinya berkisar antara 0,117 sampai 0,788 yang cendrung seragama atau tidak ada yang mendominansi kecuali pada kedalaman $0 \mathrm{~m}(\mathrm{D}=0,5405)$ yang didominasi oleh genus Synura sp. dan pada kedalaman $4 \mathrm{~m}$ ( $\mathrm{D}=0,7885)$ yang didominasi oleh genus Acanthocyclops sp.. Perairan Labuan Cermin termasuk peraran yang masih baik dari segi keanekaragaman.

\section{UCAPAN TERIMAKASIH}

Terimakasih diucapkan kepada bapak Camat Kec. Bidukbiduk yang telah memberikan ijin untuk melakukan penelitian di Labuan Cermin.

\section{DAFTAR PUSTAKA}

Asriyana \& Yuliana. (2012). Produktivitas Perairan. Jakarta: Bumi Aksara.

Banarjea, S. M. (1967). Water Quality and Soil Condition of Fish Pond in Some. Stages of India in Relation to Fish Production. Indian J. Fish
Begon, M., John L. H., \& Collin, R. T. (1986). Ecology. London: Blackwall Scientific Publication.

Costello, M. J. (2000). A Framework for an Action on Marine Biodi-versity in Ireland. Prepared for The marine institute.

Effendi, H. (2003). Telaah Kualitas Air Bagi Pengelolaan Sumber Daya dan Lingkungan Perairan. Yogyakarta: Penerbit Kanisius.

Fachrul, M. F. (2006). Metode Sampling Bioekologi. Jakarta: Bumi Aksara.

Graham, M. (2015). Marine and Fresh-water Biology. Most Landing Marine Labolatory.

Hasnawijaya. (2012). Studi Kesesuaian Lahan Budidaya Ikan Kerapu dalam Karamba Jaring Apung dengan Aplikasi Sistem Informasi Geografis di Teluk Raya Pulau Singkep, Kepulauan Riau. Journal of Aquaculture Management and Techno-logy. Semarang: Universitas Diponegoro.

Nugraha, M. F. I., Sumiarsa, G.S., Hanafi, A., \& Septory, R. (2007). Pola sebaran horizontal Copepoda di 
Perairan Gondol Bali. Pengembangan Iptek Perikanan dan Kelautan Berkelanjutan dalam Mendukung Pembangunan Nasional. Prosiding Seminar Nasional Perikanan dan Kelautan. Fakultas Perikanan dan ilmu Kelautan Univer-sitas Diponegoro. Badan Penerbit Universitas Diponegoro.

Nontji, A. (2008). Plankton Laut. Jakarta: Djambatan.

Odum, E. P. (1996). Dasar-Dasar Ekologi. Yogyakarta: Gadjah Mada Uni-versity Press.

Radiarta, N. (2013). Hubungan Antara Distribusi Fitoplankton deng-an Kualitas Perairan di Selat Alas, Kabupaten Sumba-wa, Nusa Tenggara Barat. Jakarta: Pusat Penelitian dan
Pengembangan Perikanan Budidaya.

Sachlan, M. (1982). Planktonologi. Correspohornce Course Centre.

Suryanto, A. M. (2011). Kelimpahan dan Komposisi Fitoplankton di Waduk Selorejo Kecamatan Ngantang Kabupaten Malang. Fakultas Perikanan dan Ilmu Kelautan. Universitas Brawijaya.

Sutjianto, R. (2003). Biodiversitas Plankton Sebagai Indikator Kualitas Perairan. Makassar: Univer-sitas Hasanuddin.

Thoha, H. (2004). Kelimpahan Plankton Di Perairan Bangka-Belitung dan Laut Cina Selatan, Sumatera. Jakarta: Pusat Penelitian Oseanografi, Lembaga Ilmu Pengetahuan Indonesia. 